\title{
Hazards that threaten Greek wetlands: the case of Lake Koronia
}

\author{
V. Manakou, A. Kungolos \& E. Beriatos \\ Department of Planning and Regional Development, \\ University of Thessaly, Volos, Greece
}

\begin{abstract}
Wetlands all over the world have been recognized as some of the most productive, multifunctional and dynamic ecosystems and they are under protection according to European Union legislation. However, they are under imminent threat due to increasing pollution, intensification of agriculture and rapid development activities. Lake Koronia is one of the eleven wetlands protected under the Ramsar Convention in Greece. However, it has been undergoing great degradation during the last twenty years due to the lack of a proper environmental management plan. The main activities in the wetland watershed are agriculture, industry and urban development. The aims of the present paper are to identify and represent the major ecological changes that have recently occurred, the real problems that threaten the ecosystem of Lake Koronia, as well as to make proposals that should be taken into consideration for the proper management and the conservation of the protected wetland.
\end{abstract}

Keywords: Lake Koronia, wetland threats, sustainable development.

\section{Introduction}

Wetlands are considered to be among the most important and productive ecosystems in the word, providing important functions and services such as habitat for wildlife and plants, improvement of water quality, flow and food control to ground water recharge and discharge, recreational and commercial fishing as well as other life-support functions [1]. For this reason many wetlands all over the world are protected and monitored by various governmental services [2]. 
However, nowadays wetlands are under heavy pressure. Many wetlands have been lost and degraded due to increasing pollution, intensification of agriculture, the continuing encroachment of urban developments and the rapid rate of growth of the industrial uses [3]. This degradation leads to the increasing need for the application of a proper and sustainable management plan for the protection and conservation of earth's wetlands.

More specifically, in Greece, wetlands present exceptional ecological, social and economic interest. The awareness of the importance of wetlands renders imperative the need for the reception of strict measures for their protection, as well as the adoption of environmental property management. Nevertheless, the growth of industries and urbanization led to the exploitation of our natural resources, which has as a result led to the degradation of Greek wetlands. Such an example is Lake Koronia, which while it is one of the most important wetlands in Greece, at the same time also constitutes one of the most formal examples of wetland degradation.

The objectives of the present study were to analyze the threats endangered the lake ecosystem, as well as to present the changes that have recently occurred. This information can provide an important base for the development of a national strategy for proper wetland management.

\section{Study area}

The case study in this paper is Lake Koronia, also known as Lake of Lagadas, located in the Mygdonia Basin in Northern Greece, about $15 \mathrm{Km}$ NE of the city of Thessaloniki, at a latitude of $40^{\circ} 59^{\prime} \mathrm{N}$ and a longitude of $23^{\circ} 15^{\prime} \mathrm{E}$ and with a mean altitude of $75 \mathrm{~m}$ above sea level. It also occupies an area of approximately $42 \mathrm{Km}^{2}$. Its watershed is approximately $350 \mathrm{Km}^{2}$ and formerly it drained into Lake Volvi via a modified stream channel, then to the sea, see figs. $1 \& 2$.

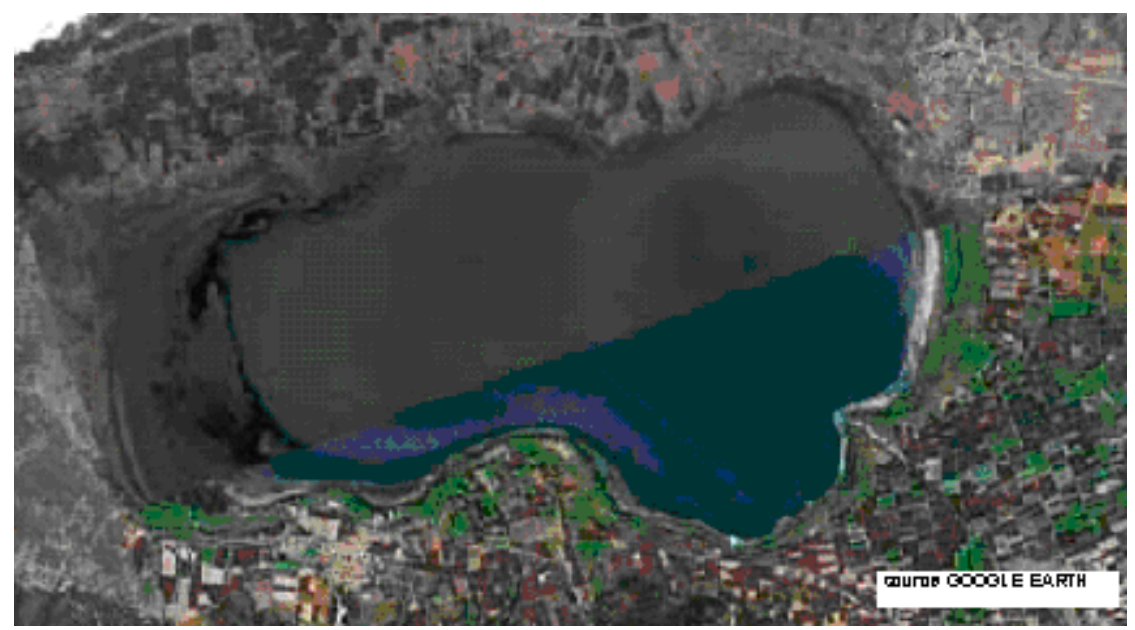

Figure 1: $\quad$ Satellite view of Lake Koronia. 


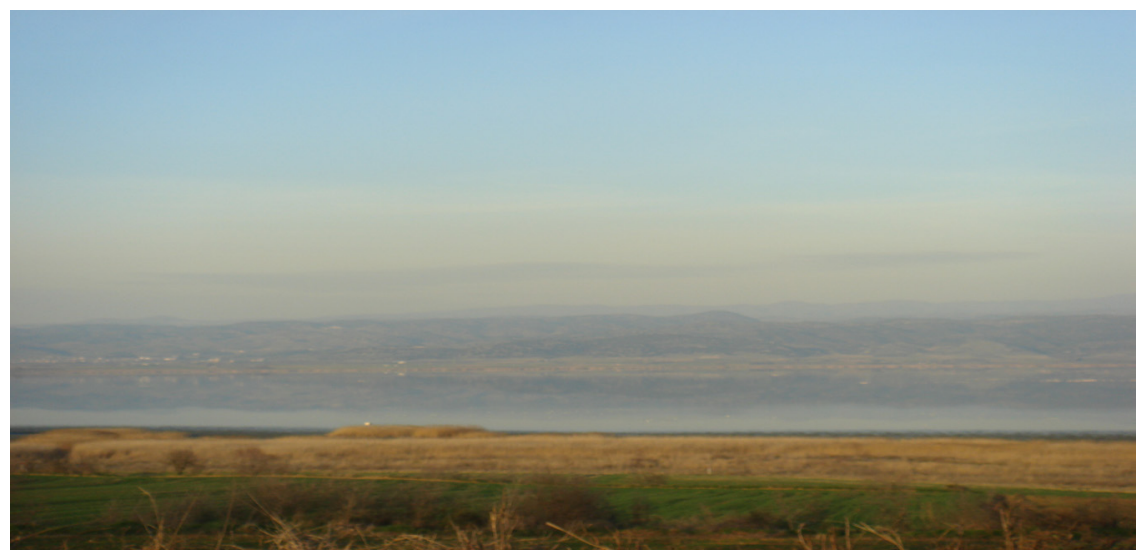

Figure 2: $\quad$ A current view of Lake Koronia.

The wetland includes important natural complex habitat types such as fresh water marsh, lacustrine and riverine forests and scrublands, as well as agricultural landscapes. The area provides an ideal habitat for a variety of flora and fauna species. It is a significant habitat of structural and species diversity (fishes, invertables, reptiles, birds, mammals), and also provides an important roosting and nesting site for many endangered bird species [4].

The whole area (Lakes Koronia and Volvi) is protected by the Ramsar Convention as a site of international importance for the value of the wetland habitat since 1975, and has been proposed as a site of Community Interest within the Natura 2000 network. In recognition of its ecological importance, it is protected by a number of national and local legal frameworks [5].

\section{Wetland threats and changes}

The sensitive ecosystem of Lake Koronia faces a number of threats and problems that cause changes to this unique and valuable resource and more specifically put it in danger of disappearing. How we reached the current state can be summarized in the following historical evolution:

- During the $1960 \mathrm{~s}$, the lake had an area of approximately $50 \mathrm{Km}^{2}$. In the beginning of the 1970s, the area was calculated at about $47 \mathrm{~km}^{2}$ and the mean depth was $5 \mathrm{~m} \mathrm{[6].}$

- At the end of 1980s, the quantity of waters was decreasing rapidly. In the period 1985-1995, a reduction of the maximum water depth of $3 \mathrm{~m}$ took place (from 4.5 to $1.5 \mathrm{~m}$ maximum depth) and the lake surface decreased to $30 \mathrm{~km}^{2}$ [7].

- In August of 1995, the reduction in the level of the lake, in combination with water contamination, led to the mass deaths of fish and birds.

- In August of 2002, the lake almost disappeared when the maximum depth dropped to $0.8 \mathrm{~m}$. The phenomenon was proved provisional, as 
the intense rainfalls during the winter months resulted in the repletion of the lake.

- In 2003, the size of lake was appreciated at $34.4 \mathrm{~km}^{2}$ and the maximum depth was $3 \mathrm{~m}$.

- In September of 2004, 30,000 birds were found dead around the lake due to a botulism outbreak [8].

- In February of 2007 the water of the lake contained toxic cyanobacteria in high concentrations.

- Finally, by September 2007, the water of the lake contained toxic cyanobacteria in extremely high concentrations and dead birds found on site included avocets, flamingos, avocets, shelducks, sandpipers and terns $[8,9]$.

From the above mentioned data, it is obvious that the ecosystem of Lake Koronia faces a very important ecological crisis. As we can see, the environmental problem of Lake Koronia has two dimensions:

- quantitative, with the progressive decline of the depth of the lake from 8 m during the 1960 s to less than $1 \mathrm{~m}$ by 2001 and

- qualitative, with the deterioration of the water quality and the classification of the lake from eutrophic to hypertrophic. The eutrofication of the lake has led to the degradation of the whole aquatic ecosystem and brings several other problems such as toxic algal blooms, low transparency, death of fish, minimisation of fish productivity, severe depletion of dissolved oxygen, loss of biodiversity, etc [10].

The understanding of the problem becomes more explicit with the report of the pressures and hazards that threaten the ecosystem and lead to the qualitative and quantitative degradation of the lake.

The identification of the main pressures for the protected wetland of Lake Koronia was based on numerous studies and management plans [11-14]. These researches have identified agricultural and industrial activities as the main factors for the changes that have occurred during recent decades on the lake.

Agricultural activities intensified in the wetland during the 1960s and, particularly in the last two decades, the number of irrigation drillings has increased rapidly, causing as a result the decrease of the water level. In addition, the change in cultivation needs led to the increase of the use of fertilizers as well as pesticides and insecticides contributing in the development of hypertrophic conditions, pollution of surface and underground water and massive deaths of fish and birds $[11,15,16]$.

During the last two decades, the area around Lake Koronia became a pole of attraction for the development of industrial units. The industrial infrastructure includes textile, dairy, agricultural and fishing industries. Some of these industries affect Lake Koronia via wastewater discharge directly into the lake, which contribute to the water quality decline. Moreover, the industrial production induces the wetland via alteration of the hydrologic budget of the watershed through groundwater pumping $[15,17]$. 
Other factors that led to the degradation of the lake are livestock and urban activities. Livestock affects the ecosystem of the lake in two ways: by discharging its wastes into the lake without treatment and by the intensification of livestock (overgrazing), witch led to the reduction of the existed vegetation. In addition to the negative water balance, the lake receives large quantities of domestic wastewater, which contributes to the water quality decline. The wastewater from the sewage systems and septic tanks from the municipalities located around the lake are ending up in the lake untreated [7]. The following table synopsizes the above mentioned threats and their impacts on the ecosystem of Lake Koronia.

Table 1: $\quad$ Wetland threats and their impacts.

\begin{tabular}{|l|l|}
\hline \multicolumn{1}{|c|}{ Pressures } & \multicolumn{1}{c|}{ Consequences } \\
\hline Intensive agricultural activities & \\
\hline Increase of irrigation drillings & Decrease of water level \\
\hline $\begin{array}{l}\text { Increase of fertilizer and pesticide } \\
\text { use }\end{array}$ & Qualitative degradation of water \\
\hline Industrial activities & \\
\hline Industrial effluents & Qualitative degradation of water \\
\hline Groundwater pumping by industries & Decrease of water level \\
\hline Urban activities & Qualitative degradation of water \\
\hline Domestic effluents & \\
\hline Livestock & Qualitative degradation of water \\
\hline Waste discharge into the lake & Vegetation degradation \\
\hline Overgrazing & \\
\hline
\end{tabular}

\section{Strategic lake management}

\subsection{Management goals}

In the case of Lake Koronia, we believe that magic solutions do not exist for the lake. The ultimate goal and essential solution is the sustainable development of the protected wetland for the rescue of the lake. This means on one hand the reservation of terms and parameters of natural operation of the lake and on the other hand the halting of pollution and the suspension of irrational use of water.

The necessary actions to achieve these aims are:

- restoration of water levels in the lake (management measures relating to the consumption of water and water enrichment of the lake)

- prevention of further pollution and degradation of the lake

- protection of the biotic environment and natural resources

- planning, implementation, management and monitoring of the programs and works that have been constituted or proposed by the responsible stakeholders and 
- $\quad$ increase knowledge and raise of awareness of the ecological, economic and social values of Lake Koronia among decision makers, local communities and visitors.

\subsection{Restoration strategies}

In order to achieve the aforementioned goals, a number of strategies are suggested. These strategies are mainly focused on the restoration of the water levels and the reduction of the pollution level of the wetland and can be summarized as follows.

\subsubsection{Water enhancement of the lake}

This strategy indicates the need for new irrigation systems that reduce both over consumption and losses of water. In parallel, the maintenance and restoration of the existing irrigation networks, as well as the limitation of water pumps and drills will help to reduce further water losses. Also, the construction of a series of regulating dams for the diversion of rainfall water to Lake Koronia can ensure the water enhancement of the lake.

\subsubsection{Qualitative and quantitative reduction of pollution}

The encumbrance of urban and industrial waste is high. This strategy requires not only the extension of the existing wastewater treatment plant of Lagadas, but the installation of a new one. In addition, the construction of proper equipment for wastewater treatment for each industrial unit is viewed as imperative.

Furthermore, sustainable agricultural practices are necessary for the prevention of further degradation of the wetland. This can be achieved through a permanent, specially designed program that will focus on the reduction of the use of fertilizers and pesticides and the wise use of agrochemicals.

\subsubsection{Reformation of agriculture}

This strategy aims to replace cultivations with high water needs by others that require a lower input of water. Furthermore, the long-term cessation of the cultivation of agricultural fields, turning to new organic or alternative cultivations and the afforestation of the revealed fields around the lake will minimize the negative effects.

\subsubsection{Monitoring system establishment}

This is a strategy that would monitor the hydrological, hydrochemical and biotic parameters of Lake Koronia. Monitoring equipment and techniques aim to establish a framework for pollution control, improvement of the quality of discharged water and pollutant sources.

\subsubsection{Increasing awareness among decision-makers and the general public}

It is suggested the decision-makers take into account the information and experience gained internationally when devising site-specific management plans.

With regard to the general public the strategy aims to organize awarenessraising activities, programmes for promoting local appreciation of the values and 
functions of the wetland, using all appropriate tools (e.g. TV-radio programmes leaflets, posters, websites etc).

\section{Conclusions}

Lake Koronia is under pressure from direct and indirect anthropogenic activities. There are two main factors that are responsible for the degradation of the wetland, intensive agricultural activities, industrial and urban wastewaters. In order to improve the environmental quality of Lake Koronia organizations of various sectors must take a cooperative approach. Therefore it is necessary to understand that the problem is not technical, but political. It is essential to specify a governmental agency to be responsible for making the proper coordination and administrative guidance. Appropriate countermeasures should also be taken for future activities and for water quality improvement plans.

\section{References}

[1] Brander, L.M., Florax, R.J.G.M. \& Vermaat, J.E., The empirics of wetland valuation: a comprehensive summary and a metaanalysis of the literature. Environmental and Resource Economics 33 (2), pp. 223-250, 2006.

[2] Töyrä, J. \& Pietroniro, A., Towards operational monitoring of a northern wetland using geomatics-based techniques. Remote Sensing of Environment, 97(2), pp. 174-191, 2005.

[3] Birol, E., Karousakis, K. \& Koundouri, P., Using a choice experiment to account for preference heterogeneity in wetland attributes: The case of Cheimaditida wetland in Greece. Ecological Economics 60, pp. 145-156, 2006.

[4] Kaiserli, A., Voutsa, D. \& Samara, C., Phosphorus fractionation in lake sediments - Lakes Volvi and Koronia, N. Greece. Chemosphere 46, pp. 1147-1155, 2002.

[5] Alexandridis, T., K., Takavakoglou, V., Crisman, T., L. \& Zalidis, G., C., Remote Sensing and GIS Techniques for Selecting a Sustainable Scenario for Lake Koronia, Greece. Environ Manage 39, pp. 278-290, 2007.

[6] Tzionas, P., Ioannidou, I., A., Paraskevopoulos, S., A hierarchical fuzzy decision support system for the environmental rehabilitation of Lake Koronia, Greece. Environ Manage 34(2), pp. 245-260, 2004.

[7] Kungolos, A., Samaras, P., Kimeroglu, V., Dabou, X. \& Sakellaropoulos, G., P., Water quality and toxicity assessment in Koronia lake- Greece. Fresenius Environmental Bulletin 7, pp. 615-622, 1998.

[8] MEDWET. www.medwet.org

[9] EKBY press conference 19 September 2007.

[10] Gantidis, N., Pervolarakis, M. \& Fytianos, K., Assessment of the quality characteristics of two lakes (Koronia and Volvi) of N. Greece. Environ Monit Assess 125, pp. 175-181, 2007. 
[11] Karavokyris and Partners, Knight Piesold, Anelixi, Agrisystems. Environmental restoration of Lake Koronia. Final report submitted to European Commission, DG XVII, 1998.

[12] Grammatikopoulou, N., Kechagias, D. \& Economidis, G., A rescue plan for Lake Koronia. Environmental Report. Greek Ministry of the Environment (in Greek), Athens, Greece. 1996.

[13] Ramboll, Lake Koronia, EU Draft Report, 1997

[14] Zalidis, G., Takavakoglou, V. \& Alexandridis, T., Revised restoration plan of Lake Koronia. Aristotle University of Thessaloniki, Department of Agronomy, Laboratory of Applied Soil Science, Thessaloniki (in Greek) 2004.

[15] Ioannidou, I., Paraskevopoulos, St. \& Tzionas, P., Fuzzy modeling of interactions among environmental stressors in the ecosystem of Lake Koronia, Greece. Environmental Management 32, pp. 624-638, 2003.

[16] Mitraki, C., Crisman, T., L. \& Zalidis, G., Lake Koronia, Greece: Shift from autotrophy to heterotrophy with cultural eutrophication and progressive water-level reduction. Limnologica 34, pp. 110-116, 2004.

[17] Piesold, K., Karavokiris, Anelixi and Agrisystems S. A. 1999. Environmental rehabilitation of Lake Koronia, Greece. Final Report. European Commission Directorate General XVI, Regional Policy and Cohesion. 